УДК 378.018.8:376-056.264-051

DOI:

Світлана Цимбал-Слатвінська, кандидат педагогічних наук, доцент Уманського державного педагогічного університету імені Павла Тичини

\title{
КОНСТРУЮВАННЯ ПОЕТАПНОГО ВИКОРИСТАННЯ ФОРМ, МЕТОДІВ, ТЕХНОЛОГІЙ ПРОФЕСІЙНОЇ ПІДГОТОВКИ МАЙБУТНІХ ЛОГОПЕДІВ
}

У статті розкрито проблему конструювання поетапного використання форм, методів, технологій професійної підготовки майбутніх логопедів. Визначено найбільш ефективні форми, методи, технології. Встановлено, ш⿻о конструювання поетапного освоєння активних форм та методів включає ряд послідовних етапів: перший, адаптаційний, другий - індивідуальні та групові вправи з розвитку досвіду сприйняття інших людей і розвитку власної рефлексї, третій - аналіз конкретних педагогічних ситуацій, четвертий семінари-ігри, заняття-реклама; заняття-вистава тощуо, n'ятий - спеціальні рольові ігри, шостий комбінація гри й імітацї; сьомий - життева практика.

Ключові слова: конструювання; поетапне використання; форми; методи; технологї; професійна підготовка; логопед.

Табл. 1. Літ. 10.

Svitlana Tsymbal-Slatvinska, Ph.D. (Pedagogy), Associate Professor of the Special Education Department, Pavlo Tychyna Uman State Pedagogical University

\section{CONSTRUCTION OF GRADUAL USE OF FORMS, METHODS, TECHNOLOGIES OF PROFESSIONAL TRAINING OF SPEECH THERAPISTS}

The paper deals with the issue of constructing the gradual use of forms, methods, technologies of professional training of speech therapists. The most effective forms are defined as lectures in online laboratories, lectures in the mode of television (video) conferences, lectures-presentations, problematic lectures, "oral journal", creative groups, training sessions, workshops, seminars, coaching, self-study, work with e-library, work with databases, visits to preschool educational institutions. The most effective methods are defined as role-playing and business games, brainstorming, consultations-dialogues, consultations-paradoxes, "pollen" method, discussions, "round table" method, master class, case study method, individual educational-correction program, modelling, projecting, training in pairs, solving practical-oriented tasks. The most effective technologies are defined as teaching based on the factors of linearity and concentricity in organizing the process of preparing speech therapists for professional activity, modelling future professional activities and organizing the students'self-study by technological cards and assessing their readiness for professional activities based on monitoring of their individual professional growth, using information and communication technologies in the information and educational environment of higher education institutions. The author has revealed that constructing a gradual use of active forms and methods of professional training of speech therapists has several stages: the first stage - communication training, exercises, filling in the individual student cards, the second stage - individual and group exercises to develop the experience of perception of others and the self-reflection, the third stage - analysing the specific pedagogical situations, solving pedagogical tasks, discussing issues in microteams (seminar-briefing), a method of "incident", intellectual games, the fourth stage - the workshop games like "What, Where, When?" and "Brain Ring", the cognitive ring "Swing", class-advertising, class-performance, etc.), the fifth stage - specific role-playing games, the sixth stagea combination of game and imitation, the seventh stage is real-world practice.

Keywords: construction; gradual use; forms; methods; technologies; training; a speech therapist.

П остановка проблеми. Інтерес до активних форм і методів навчання викликаний гострою потребою в оптимізації освітнього процесу, поліпшення сучасної освітньої системи за рахунок майстерності педагога, а не перевантаження студентів.

Аналіз основних досліджень. Вдосконаленню процесу професійної підготовки майбутніх логопедів, зокрема на основі використання форм, методів, технологій, науковцями приділено значну увагу (І. Андрусьова, О. Баскакова, А. Богуш, О. Боряк, Л. Волкова, В. Глухов, С. Заплатна, Н. Ільїна, В. Ільяна, В. Кисличенко, Ю. Клочкова, О. Корзун, О. Кузенко, Л. Лісова, В. Литвиненко, 3. Ленів, М. Лепетченко, Н. Мельниченко, П. Мозгова, Л. Немикіна, Л. Потапова, Ю. Рібцун, Н. Савінова, І. Сергєєва, С. Соботович, О. Соловей, О. Степанов, О. Стецик, В. Тарасун, Л. Томіч, Л. Трофименко, М. Фомичева, М. Хватцев, Л. Черніченко, С. Чухачева, М. Шеремет та ін. Дослідники вважають, що сенс розробки й 


\section{КОНСТРУЮВАННЯ ПОЕТАПНОГО ВИКОРИСТАННЯ ФОРМ, МЕТОДІВ,}

ТЕХНОЛОГІЙПРОФЕСІЙНОӤ ПДГОТОВКИ МАЙБУТНІХЛОГОПЕДІВ

використання в освітньому процесі активних форм і методів навчання полягає не в ефекті новизни, а в підвищенні якості підготовки фахівця: звичайні форми навчальної роботи (лекції, семінари, лабораторні та практичні заняття, консультаціі), мають обмежені можливості прояву активності і творчості студента. Активні форми і методи навчання в одному випадку ставлять його на місце режисера, в іншому - вчителя, в третьому - консультанта, в четвертому - автора або художника, у п'ятому - організатора певної діяльності дітей або однокурсників, у шостому учня, в сьомому - організатора освітнього процесу тощо, і чим різноманітніше виконуються студентом ролі і його позиція в діяльності, тим більш різнобічно розвивається особистість майбутнього фахівця $[1,59]$.

У сучасній вищій школі за кордоном також відзначається підвищений інтерес до активних методів навчання. У номенклатуру форм i методів активного навчання, які відповідають новим цілям і змісту освіти, Al. Astin включає: метод проектів і пошуково-дослідницький, що дозволяють студентам брати участь у вирішенні наукових проблем; інтегровані семінари, які організовуються і проводяться викладачами різних галузей знань; навчальні громади студентів, що організовуються на основі певних ознакздібностей, схильностей, професійних інтересів, що створюють відчуття групової ідентичності; колоквіуми і різні форми індивідуалізації навчання $[8,161$ - 162]. Гнучка система активних форм i методів навчання охоплює не тільки умови формування навчально-пізнавальних способів дій, а й соціально-комунікативні та особистіснорефлексивні аспекти учіння.

На думку американських фахівців з педагогіки вищої школи, активні форми і методи навчання, безсумнівно, сприяють формуванню цілісної структури професійної діяльності, набуття навичок соціальної взаємодії, співпраці, розвитку творчих здібностей [8, 140].

На сьогодні існує безліч форм, методів та засобів розвитку професійної компетентності фахівця, зокрема логопеда. Найбільш ефективними формами, на наш погляд є: відвідування дошкільних освітніх установ, занять 3 метою обміну досвідом; семінари теоретичні й семінари-практикуми, спецсемінари, лекції, які читають висококваліфіковані фахівці; конференції, відвідування яких дасть фахівцеві можливість переглядати не тільки методи, засоби, форми, технології навчання і корекції, але i ставлення до професійної діяльності в цілому, що позитивно позначається на бажанні фахівця реалізовуватися як професіоналу.
Необхідність пошуку нових ефективних освітніх форм і методів, що забезпечують реалізацію практико-орієнтованого підходу, обгрунтована В. Ванієвою, до яких віднесено такі: лекція з запланованими помилками, ділова гра, “кейс-метод”, метод “Пилка”, складання портфоліо, метод проектів тощо і реалізація інноваційної освітньої моделі - участь студентів у діяльності навчально-наукової “Лабораторії інклюзивної освіти”, де під керівництвом викладачів студенти здійснювали основні види діяльності логопеда: діагностику відхилень у мовленнєвому розвитку й розвитку інших психічних функцій, розробку й реалізацію індивідуальної корекційної програми, консультування батьків [2, 4].

Серед методів Н. Безсмертна найбільше визнання віддає таким, як аналіз конкретних ситуацій, вирішення педагогічних завдань, метод інциденту, дидактичний тренінг, метод розігрування ролей, ігрове проектування, педагогічні ігри та інші методи активного навчання, що сприяють розвитку творчого та практичного професійного мислення, активності й самостійності, ініціативної поведінки, самооцінки самоорганізації, у підсумку особистісної орієнтації в навчальній діяльності та індивідуальної творчості $[1,60]$.

Мета статті - розкрити проблему конструювання поетапного використання форм, методів, технологій професійної підготовки майбутніх логопедів.

Виклад основного матеріалу. Розглянемо можливості освітнього середовища у використанні інноваційних форм та активних методів та технологій та їх поетапному узгодженні.

Серед організаційних форм підвищенню активності й результативності роботи студентів у процесі навчання сприяє особливе проведення лекцій та практичних занять. У роботі зі студентами необхідні теоретичні відомості викладалися у вигляді проблемних лекцій для осмислення теоретичного матеріалу (теми: “Предмет і завдання логопедії. Науковотеоретичні основи логопедії. Зв'язок логопедії 3 іншими науками”. “Причини мовленнєвих порушень. Класифікація мовленнєвих порушень”), спрямованих на розширення, деталізацію знань, на вироблення і закріплення навичок професійної діяльності. На лекціях використовувалися різні структурно-логічні схеми (мнемосхеми), кожна 3 яких мала свою змістову суть і значення. Мнемосхема - це умовне зображення будь-якого явища, процесу, проблеми, поняття, виконане у 


\section{КОНСТРУЮВАННЯ ПОЕТАПНОГО ВИКОРИСТАННЯ ФОРМ, МЕТОДІВ,}

ТЕХНОЛОГЙПРОФЕСІЙНОӤ ПІДГОТОВКИ МАЙБУТНІХЛОГОПЕДІВ

вигляді креслення, що зображує відношення, зв'язки наявних частин цілого, що допомагає сприйняттю, осмисленню цих явищ, що полегшує запам'ятовування і збільшує обсяг пам'яті шляхом утворення штучних асоціацій. Студенти на основі запропонованої схеми використовували ілюстрацій до теоретичних положень, на основі яких відстежувалися взаємозв'язки звуків під час постановки їх у дитини. Студенти на основі запропонованої схеми простежують взаємозв'язок звуків під час постановки їх у дитини.

В організації роботи студентів застосовували різні техніки, серед яких коучинг. Різниця між коучингом і лекцією в тому, що перший збуджує активність, а друга її обмежує. В основі коучингу (теми: “Анатомо-фізіологічні механізми мовлення”, “Загальне уявлення про дислалії як порушення вимови”) покладено використання спеціальних технологій, які допомагають організувати процес вільної комунікації, обмін думками, судженнями, і підводять студента до прийняття професійно грамотного рішення завдяки реалізації його внутрішніх можливостей.

У рамках формувального експерименту застосовано семінар як обов'язковий складник із логопедичної техніки в тій чи іншій ситуації обстеження мовлення. Під час розгляду тем “Рефлексивні вміння логопеда”, “Диференційна діагностика мовленнєвих порушень” розглядалися діагностичні обстеження мовленнєвого розвитку в дітей на корекційно-логопедичних заняттях, консультаціях майбутнього логопеда з батьками.

На семінарах вирішувалося два завдання: основне (з теми семінару) і супутнє (3 логопедичної техніки), в результаті чого відбувалася інтеграція навчальної та практичної діяльності студентів. Упровадження комплексу завдань проходило в три етапи. На першому етапі створювалася позитивна установка на сприйняття й осмислення інформації про професійну діяльність логопеда; стимулювалася внутрішня мотивація студентів на підвищенні власної професійної компетентності. На другому етапі проводилися заняття у групах: виконувалися практичні завдання, проводилися тренінгові вправи, ділові ігри, майстер-класи тощо. На третьому етапі здійснювалися консультації 3 виконування самостійної роботи.

Запропоновано написання рефератів із проблеми особливостей роботи 3 дітьми 3 порушенням мовлення; участь у диспуті на тему: “Актуальність проблеми підготовки студентів до роботи з дітьми з мовленнєвими порушеннями”; включення студентів у рефлексивну діяльність. Для рефератів запропоновано такі теми:
“Особливості навчання дітей старшого дошкільного віку з порушенням мовлення в дошкільному закладі”, “Вплив порушення мовлення на формування особистісних особливостей дітей”, “Корекційна робота 3 дітьми дошкільного віку з порушенням мовлення", “Особливості формування зв'язного мовлення у дітей дошкільного віку, що мають виражений мовний дефект", "Готовність до шкільного навчання дітей дошкільного віку з порушенням мовлення" тощо.

Спецпрактикум використано на завершальному етапі теоретичного навчання для відпрацювання і закріплення практичних умінь майбутніх логопедів. Практикум займає проміжне положення між лекцією і консультацією. 3 консультацією практикум зближують високий ступінь індивідуалізації навчання, можливість спостерігати не тільки за результатом, а й за процесом навчання, оперативно корегувати його, домагатися більшої ефективності. Практикум допомагає збільшити глибину вивчення окремих навчальних тем, підвищує інтенсивність і самостійність навчальної діяльності: виділити у проблемній ситуації навчальне завдання, знайти шляхи їі вирішення, використовувати при цьому різноманітні джерела - все це вимагає від студентів тривалих інтелектуально-вольових зусиль, підкріплених стійкою мотивацією $[3,116]$.

У розробці циклу практичних занять (практикуму) ми намітили для відпрацювання ті вміння, якими студенти повинні опанувати до закінчення курсу. Спільні вміння, необхідні для проведення різних заходів із дітьми, студенти опановували на практичних заняттях. Специфічні вміння відпрацьовувалися на практикумі, оскільки вони вимагають спеціальної методики формування (наприклад, уміння проводити обстеження мовлення у дітей, підбирати методики обстеження, матеріал для дослідження тощо).

Структура проведеного нами практикуму передбачала: вступний інструктаж, у процесі якого актуалізувалися опорні знання студентів, здійснювалася постановка мети майбутньої роботи, давалися загальні вказівки їі виконання; виконання роботи студентами; підведення підсумків.

Проведення практичних занять дозволило застосувати активні методи і засоби навчання студентів, що надають можливість для творчого застосування отриманих знань і способів орієнтації в умовах професійної діяльності. Під час розбору навчальних ситуацій на практичних заняттях відтворювалися особливі випадки у корекційній роботі 3 дітьми 3 порушенням 


\section{КОНСТРУЮВАННЯ ПОЕТАПНОГО ВИКОРИСТАННЯ ФОРМ, МЕТОДІВ,}

ТЕХНОЛОГІЙПРОФЕСІЙНОӤПІДОТОВКИ МАЙБУТНІХЛОГОПЕДІВ

мовлення не тільки в умовах дошкільних закладів, а й в умовах системи охорони здоров'я, а також в умовах інклюзії. На практичних заняттях $з$ тем: “Організація логопедичного впливу при порушеннях звуковимовних відношень в дитячому садку”, “Етапи та зміст логопедичної роботи при дизартрії у дітей. 1 етап корекційної роботи”, “Дидактичний матеріал для проведення обстеження звуковимови”, “Картотека мовного матеріалу на автоматизацію і диференціацію приголосних звуків (вірші, скоромовки)", “Картотека дидактичних ігор на автоматизацію i диференціацію звуків".

Проведення тренінгових занять “Мистецтво промови”, “Тренінги з постановки правильного дихання”, “Зняття м'язової напруги” характеризувалися такими особливостями: впливом на емоційний стан учасників; зняттям напруженості, розрядкою обстановки і відпочинку під час занять; вільним і безпосереднім проявом учасниками своїх думок, почуттів; увагою й інтересом з боку партнерів по спілкуванню і взаємодії тощо.

Заняття у формі конференції (теми: “Логопедія ХХІстоліття. Традиціїіновації”, “Здоров’язбережувальні й логопедичні технології в освіті: традиції, пошук, новаторство") актуальні під час підведення підсумків роботи студентів над актуальною загальною науково-методичною проблемою.

Розвиток критичного, творчого осмислення $\mathrm{i}$ застосування досягнень науки і передового професійного досвіду забезпечила робота студентів у творчих групах. Прикладом $є$ планування учасниками творчої групи індивідуальної роботи з дітьми $з$ порушенням мовлення. У ході роботи виникла ідея розробки планів-карток індивідуальних занять, які використовуються на всіх етапах корекції порушення мовлення у дошкільників (постановка звуків, автоматизація, диференціація тощо).

Алгоритм написання планів-карток занять передбачає такі етапи: підготовчий, етап формування первинних вимовних умінь і навичок, етап формування комунікативних умінь і навичок. Після розробки занять (близько 60) творча група опрацювала їх конспекти, привела їх оформлення до єдиного варіанту, відкоригувала, ліквідувала помилки різного характеру. У подальшому ними розроблено варіант оформлення журналу індивідуальної корекційно-відновлювальної роботи у формі таблиці: по вертикалі вказуються прізвища, імена дітей, по горизонталі дні тижня. У пересічних клітинах вказується тема і код картки. Це економить робочий час: немає необхідності написання щоденних планів індивідуальних занять.
Має характерні особливості підготовки студентів така форма навчання, як “усний журнал”. Творча група (“редакційна колегія”) заздалегідь моделювала “журнал”, його структуру, визначала кількість сторінок, їхні назви і зміст, продумувала "пожвавлення" кожної сторінки. Використано різноманітні жанри журналістики: репортажі, розповіді, замальовки, інтерв'ю, гуморески, вірші, пародії. Здійснювалося оформлення на сторінках журналу спеціальної вітрини або динамічного стенду “Чого вчитися у колег?".

Серед активних методів навчання використано такі: ігрові [2; 6], “пилка”, дискусії, круглий стіл, майстер-клас, моделювання, кейс-метод, вирішення практико-орієнтованих завдань. Для розкриття теми “Організація роботи логопеда 3 батьками в умовах дитячого садка” проводилися рольові ігри: “Знайомство з батьками дітей, які мають порушення мовленнєвого розвитку. Збір анамнезу”, “Проведення батьківських зборів, консультацій для батьків".

Імітаційні ігри є особливим методом, структурою для зберігання, передачі й отримання смислів через проектування учасниками своїх ідей щодо заданої проблеми, спільний аналіз їх до того моменту, коли певне рішення задовольнить усіх або більшість гравців.

D. Gehris стверджує, що імітаційна гра сприяє розвитку творчих здібностей студентів комбінація гри й імітації, тобто систематизована абстракція в поєднанні з частковим відтворенням у процесі навчального заняття виробничих умов з метою наближення підготовки фахівців до умов реальної дійсності $[9,136-138]$.

Відмінність імітаційної гри від рольової в тому, що рольова гра входить до імітаційної, але додаються нові компоненти: на додачу до ролей i сценаріїв учасники отримують список цілей, на які необхідно орієнтуватися, відповідно до яких будують свою поведінку, свою лінію в грі; перелік ресурсів, що $\epsilon$ в розпорядженні учасників гри, звід правил для учасників, порядок гри, наслідки порушень правил і багато іншого. Акцент робиться на виробленні взаємодії, взаєморозумінні, спільності, а не на виконанні ролей. Відмінність від ділової гри у тому, що ділова гра може виступати як імітаційна схема тієї ситуації, яка цікавить логопеда. Як модель ділова гра має “знакові можливості" широкого діапазону: можуть застосовуватися як власне знакові засоби - правила, блок-схеми, структурні зображення, так і власне ігрові.

G. Neiswand зазначає, що імітаційні ігри застосовуються в тих випадках, коли через брак 


\section{КОНСТРУЮВАННЯ ПОЕТАПНОГО ВИКОРИСТАННЯ ФОРМ, МЕТОДІВ,}

ТЕХНОЛОГЙИРОФЕСІЙНОӤ ПДГОТОВКИ МАЙБУТНІХЛОГОПЕДІВ

часу або фінансів неможлива практика за фахом в інших країнах [10, 376 - 381]. Ідея американського дослідника може знайти своє застосування, в деякій інтерпретації сприяти розвитку професійної компетентності майбутнього логопеда.

Запропоновано імітаційну гру: "Обстеження мовленнєвого розвитку дошкільника”, "Гармонізація поведінки у дитини з порушенням мовлення”, “Бесіда з батьками про необхідність взаємодії з логопедом в корекції мовленнєвих порушень дитини".

Ефективним методом проведення ділової, рольової чи імітаційної гри є “мозкова атака”, суть якої в організації колективної творчої роботи 3 вирішення складної для педагогічного колективу проблеми шляхом висунення і обгрунтування нових ідей, цілеспрямованого творчого пошуку. Запропонована структура мозкової атаки: визначення завдання й мети, ознайомлення 3 порядком роботи і сутністю кожної ролі (“генератори ідей“, “резонатори”, “інформатори”), усвідомлення принципів, правил проведення “мозкової атаки”, розминка, тренувальні вправи, оголошення проблеми та ії̈ обдумування, пошук рішень (основна робота), активна діяльність генераторів ідей, резонаторів, інформаторів, підведення підсумків роботи групою експертів, ведучим, прийняття рішення про реалізацію запропонованих ідей.

Метод "Пилка" є груповим методом, у якому студенти організуються у групи по кілька осіб для роботи над навчальним матеріалом, який розбитий на фрагменти (логічні або смислові блоки). Наприклад, у темі “Характеристика мовленнєвих процесів у дітей з порушенням мовлення” можна виділити такі блоки інформації: особливості мислення, пам'яті, уваги, сприйняття, емоційновольова сфера. Кожен член групи знаходить матеріал зі свого напряму. Студенти обмінюються інформацією як експерти 3 означеного питання та повертаються у свої групи і навчають інших членів групи того, що дізналися самі. Ті, у свою чергу, доповідають про свою частину завдання (як зубці однієї пилки). Сдиний шлях освоїти матеріал усіх фрагментів - це уважно слухати партнерів команди і робити записи в зошитах. Звітує за всією темою кожен окремо і вся команда в цілому.

Під час підготовки проведення дискусії творча група заздалегідь з'ясовувала девізи, педагогічне кредо кожного учасника, організовувала діяльність прес-центру, проводила опитування та анкетування, готувала інформаційні стенди про професійні якості логопедів, проводила консультації, надавала допомогу в підготовці до дискусії.

Серед активних методів підготовки майбутніх логопедів використано круглий стіл. "Круглий стіл” передбачає спільне обговорення та обмін думками з певної проблеми [5, 81].

Наприклад, як варіант запропоновано організацію круглих столів на теми “Сучасне методичне видання на допомогу логопедові”, “Імідж сучасного логопеда", “Сучасні прийоми логопедичної техніки" тощо.

Метод майстер-класу використано з метою пропаганди перспективного досвіду з таких проблем: диференціація навчання в логопедичній групі, діагностика рівня розвитку навчальних досягненні вихованців, організація колективної творчої діяльності, застосування ефективних форм і методів корекційно-розвивальних робіт, удосконалення системи логопедичного навчання батьків, технологія підготовки та проведення батьківських зборів тощо. Для проведення майстер-класу обрано теми: “Логопедичний масаж”; “Обстеження мовленнєвого розвитку в дітей”, “Точковий масаж у логопедичній практиці".

3 метою формування мотиваційної спрямованості особистості майбутнього логопеда до розвитку монологічного мовлення дітей методом моделювання, а також зацікавленого ставлення до занять майбутні логопеди на лекціях перетворювали науковий текст на схему-модель для ефективного його запам'ятовування i відтворення. Кодування наукового тексту починається з його аналізу і виділення головної ідеї тексту. Далі студенти складають план і розбивають текст на частини (речення, словосполучення, слово). Лексичні одиниці студенти перетворюють на знаки. На перших етапах роботи студентам пропонуються короткі уривки наукових текстів, які пов'язані з темою лекційного або практичного заняття. Далі збільшується обсяг наукових текстів. Для формування у майбутніх логопедів дій моделювання монологічного мовлення використано конструювання моделей, запропоноване Е. Чухачевою, яка включає такі етапи: складання моделі власного висловлювання, вибір об'єкта або явища для побудови монологічного мовлення дошкільника, розробка наочної моделі мовного висловлювання дошкільника (аналіз об'єкта монологу, побудова моделі розповіді), самооцінка дій студента з побудови монологічного мовлення дошкільника [7, 17].

Метод моделювання застосовувався у розробці індивідуальної освітньо-корекційної 


\section{КОНСТРУЮВАННЯ ПОЕТАПНОГО ВИКОРИСТАННЯ ФОРМ, МЕТОДІВ,}

ТЕХНОЛОГЙ̆ПРОФЕСІЙНОЇПІДГОТОВКИ МАЙБУТНІХЛОГОПЕДІВ

програми, планування корекційно-розвивальної роботи на основі результатів психологопедагогічної діагностики осіб з порушенням мовлення. Для реалізації цього завдання в дослідженні зроблено спробу навчання майбутніх логопедів розвитку монологічного мовлення дошкільників за допомогою таких ефективних засобів, як кодування наукового тексту, конструювання моделей монологічного мовлення, вирішення професійно орієнтованих завдань, імітаційне моделювання процесу формування монологічного мовлення дошкільників (ділова гра).

У процесі дослідження здійснювався вирішенням конкретних завдань-ситуацій (кейсів), розбір яких $\epsilon$ приводом подумати й обмінятися думками про мету, зміст, прийоми і методи навчання дітей, про фактори сприятливого або несприятливого впливу на їхній розвиток. Для подолання труднощів у спілкуванні 3 дітьми 3 порушенням мовлення та їхніми батьками студентам пропонувалися педагогічні завдання, у процесі вирішення яких майбутні логопеди могли б представити свої індивідуальні прийоми побудови моделей взаємовідносин 3 дітьми 3 порушенням мовлення і їхніми батьками.

Кейс-технологія дозволяє демонструвати теоретичний матеріал з погляду подій, що дає можливість формувати в учнів уміння працювати 3 інформацією, логічно думати, аналізувати реальні процеси і приймати оптимальні рішення $[4,134-140]$.

Вирішення професійно орієнтованих завдань включає три етапи: аналітичний, який починається 3 аналізу та оцінки ситуації і закінчується формулюванням завдання, що підлягає вирішенню; моделювальний, коли плануються і моделюються способи вирішення поставленого завдання і розробляється конкретна модель цього рішення; виконавський, пов'язаний $з$ практичною реалізацією моделі.

Проведений аналіз інноваційних форм та активних методів забезпечення процесу професійної підготовки майбутніх логопедів в умовах інформаційно-освітнього середовища вищих навчальних закладів дав можливість здійснити конструювання поетапного освоєння активних форм та методів для формування готовності майбутніх логопедів до професійної діяльності, що показано у таблиці 1.

Отже, конструювання поетапного освоєння активних форм та методів включає ряд послідовних етапів: перший, адаптаційний тренінги спілкування, вправи на розвиток спостережливості, інтуїції, чутливості до поведінки один одного; вправи на релаксацію, оптимізацію емоційного стану і настрою, заповнення індивідуальної карти студента 3 самоаналізом рівня сформованості ключових професійних компетентностей.

Другий етап - індивідуальні та групові вправи 3 розвитку досвіду сприйняття інших людей і розвитку власної рефлексії, оволодіння навичками комунікації в ігровій взаємодії; психотехнічні ігри 3 формування впевненості в собі, позитивної атракції.

Використані на третьому етапі методи навчання: аналіз конкретних педагогічних ситуацій, вирішення педагогічних завдань, метод “інциденту”, обговорення проблем у мікрогрупах (семінар-брифінг), обговорення проблем з різних позицій (теми: “Поняття”, “Схема”, “Апологет”, “Опозиція”, “Практик”, “Поет”, “Питання”, “Експерт”, інтелектуально-пізнавальні ігри, застосовуються у двох варіантах: у вигляді дискусії - обговорення повністю контролюється ведучими, і як вільна дискусія - за мінімального втручання ведучого в хід обговорення.

Четвертий етап - семінари-ігри “Що, де, коли?" або “Брейн-ринг”, гра-подорож, пізнавальний ринг “Гойдалки”, заняття-реклама; заняття-вистава (сценічна дія у вигляді карнавалу, наукового симпозіуму, “судового засідання" тощо).

П'ятий етап - спеціальні рольові ігри, які будуються на розвитку певного сюжету, який задається вхідними даними як основа взаємин між реальними людьми в певній ситуації. Розвиток подій залежить від ініціативності, фантазії і життєвого досвіду учасників.

Імітаційні ігри на шостому етапі являють собою комбінацію гри й імітації; основна ознака імітаційних ігор - загальний предмет (модель) діяльності, який утворює основу для спілкування, його базового змісту, створення орієнтування на предмет i, таким чином, перетинання діяльності або ієрархії дійсних мотивів, властивих спілкуванню суб'єктів. Сценарій проведення імітаційної (навчальної ділової) гри на тему: “Основні напрями педагогічної допомоги дітям із порушенням мовлення” представлений у додатку Л. Включає в себе дві частини: перша частина “Психолого-медико-педагогічна консультація", друга частина - "Педагогічна рада дошкільного навчального закладу”. Ця тема є підсумковою розділу “Основи корекційної педагогіки”.

Сьомий етап - життєва практика.

Висновки. Отже, для розкриття проблеми конструювання поетапного використання форм, методів, технологій професійної підготовки 


\begin{tabular}{|c|c|c|}
\hline \multicolumn{3}{|c|}{ Конструювання поетапного освосння активних форм, методів і технологій } \\
\hline Етап & Мета & Зміст \\
\hline I & $\begin{array}{l}\text { Взаємне звикання: підвищення } \\
\text { чутливості, уваги до своїх почуттів, } \\
\text { слів і співвідношення своїх намірів } 3 \\
\text { діями інших. Створення довірчого } \\
\text { спілкування, позитивного настрою }\end{array}$ & $\begin{array}{l}\text { Тренінги спілкування, вправи на розвиток } \\
\text { спостережливості, інтуїції, чутливості один до одного, } \\
\text { вправи на релаксацію, оптимізацію емоційного стану й } \\
\text { настрою, заповнення індивідуальної карти студента } 3 \\
\text { самоаналізом рівня формування ключових професійних } \\
\text { компетентностей }\end{array}$ \\
\hline II & $\begin{array}{l}\text { Встановлення і розвиток контактів } \\
\text { між студентами і викладачем у } \\
\text { процесі спільної діяльності: обмін } \\
\text { інформацією, вироблення єдиної } \\
\text { стратегії взаємодії. сприйняття і }\end{array}$ & $\begin{array}{l}\text { Індивідуальні та групові вправи з розвитку досвіду } \\
\text { сприйняття інших людей і власної рефлексії, } \\
\text { групові вправи і тренінги з оволодіння навичками } \\
\text { комунікації в ігровій взаємодії, психотехнічні ігри з } \\
\text { формування упевненості в собі }\end{array}$ \\
\hline III & $\begin{array}{l}\text { Освоєння навичок діалогічного } \\
\text { спілкування, що сприяє зближенню } \\
\text { учасників дискусії, що спонукає } \\
\text { студентів до усвідомлення } \\
\text { відмінностей між ними, вміння їх } \\
\text { співвідносити, об’єднувати, } \\
\text { адаптуватися до нового змісту }\end{array}$ & $\begin{array}{l}\text { Аналіз конкретних педагогічних ситуацій, вирішення } \\
\text { педагогічних завдань, обговорення проблем у мікрогрупах } \\
\text { (семінар-брифінг), обговорення проблем із різних позицій } \\
\text { (модель позиційного навчання), інтелектуально-пізнавальні } \\
\text { ігри, проблемний стіл, майстер-клас, моделювання } \\
\text { освітньої діяльності, метод проектів, “круглий стіл”, } \\
\text { семінар, “мозкова атака”, естафета, дебати, навчання в } \\
\text { парах }\end{array}$ \\
\hline IV & $\begin{array}{l}\text { Набуття досвіду рольової взаємодії; } \\
\text { узагальнення і поглиблення } \\
\text { теоретичної підготовки; творче } \\
\text { самовираження і самоствердження. }\end{array}$ & $\begin{array}{l}\text { Семінар-гра типу “Шо? Де? Коли?” або “Брейн-ринг”, } \\
\text { семінар-шоу, творча дискусія, засідання клубу знавців } \\
\text { логопедії, семінар-аукціон, гра-подорож, пізнавальний ринг } \\
\text { “Гойдалки”, заняття-спектакль }\end{array}$ \\
\hline V & $\begin{array}{l}\text { Освоєння прийнятої ролі; навчання } \\
\text { вмінь і навичок, необхідних для } \\
\text { успішного вирішення професійних } \\
\text { завдань }\end{array}$ & $\begin{array}{l}\text { Дидактичний тренінг, рольове розігрування ситуацій } \\
\text { професійної діяльності логопеда дошкільного закладу }\end{array}$ \\
\hline VI & $\begin{array}{l}\text { Вироблення здатності до творчої } \\
\text { взаємодії: формування цілісної } \\
\text { структури професійної діяльності; } \\
\text { наближення підготовки фахівців до } \\
\text { умов реальної професійної }\end{array}$ & $\begin{array}{l}\text { Ігрове проектування, педагогічні імітаційні ігри (навчальні } \\
\text { ділові ігри): “Психолого-медико-педагогічна консультація”; } \\
\text { “Індивідуальне логопедичне заняття”; “Батьківські збори”; } \\
\text { “Логопедична науково-практична конференція”" }\end{array}$ \\
\hline VII & $\begin{array}{l}\text { Адаптація до умов майбутньої } \\
\text { професійної діяльності. }\end{array}$ & $\begin{array}{l}\text { Корекційно-логопедична робота в дошкільному освітньому } \\
\text { закладі; соціально-педагогічна робота в соціумі; } \\
\text { дослідницька діяльність, захист творчих робіт, панорама }\end{array}$ \\
\hline
\end{tabular}

майбутніх логопедів підібрано найбільш ефективні. Визначено ряд послідовних етапів їх застосування: перший, адаптаційний - тренінги спілкування, вправи, заповнення індивідуальної карти студента, другий - індивідуальні та групові вправи 3 розвитку досвіду сприйняття інших людей i розвитку власної рефлексії, оволодіння навичками комунікації в ігровій взаємодії, третій - аналіз конкретних педагогічних ситуацій, вирішення педагогічних завдань, метод “інциденту”, обговорення проблем у мікрогрупах (семінарбрифінг), інтелектуально-пізнавальні ігри, четвертий - семінари-ігри “Що, де, коли?” або “Брейн-ринг”, гра-подорож, пізнавальний ринг “Гойдалки”, заняття-реклама; заняття-вистава тощо), п'ятий - спеціальні рольові ігри, шостий комбінацію гри й імітації; сьомий - життєва практика.

\section{ЛІТЕРАТУРА}

1. Бессмертная Н. А. Организационно-педагогические условия развития профессиональной компетентности будущих логопедов сельских образовательных учреждений: дис. ... канд. пед. наук. Москва, 2003. 168 с.

2. Ваниева В. Ю. Практико-ориентированный подход к подготовке студентов - будущих логопедов к профессиональной деятельности. Интернет-журнал “Науковедение”. 2015. Т. 7, № 5. URL: https://naukovedenie.ru/PDF/80PVN515.pdf (дата обращения: 04.04.2019).

3.Жукапинская Е. Н.Формированиепрофессиональной компетентности будущегоучителя-логопеда: дис. ... канд. пед. наук. Липецк, 2008. 226 с.

4. Полат Е. С., Бухаркина М. Ю. Современные педагогические и информационные технологии в системе образования: учеб. пособ. 2-е изд., стереотип. Москва, 2008. 368 с. 
5. Стахова Л. Л. Проектирование методической системы развития профессиональной компетентности учителя-логопеда дошкольного образовательного учреждения в условиях профессиональной среды: дис. ... канд. пед. наук. Тамбов, 2010. 195 с.

6. Султанова Р. М. Формированиепрофессиональной компетентности будущего учителя-логопеда в учебно-педагогической, производственной практике повышенного уровня: дис. ... канд. пед. наук. Ижевск, 2005. 226 с.

7. Чухачева Е. В. Формирование готовности будущих педагогов к развитию монологической речи детей дошкольного возраста в образовательном процессе вуза: автореф. дис. ... канд. пед. наук. Брянск, 2012. 23 с.

8. Astin A. W. Achieving Educational Excellence. San-Francisco: Jossey-Bass Publishers, 1985. 485 p.

9. Gehris D. O. The use of simulation in business education. Business education. 1982. No. 7. pp. 136-138.

10. Öster A-M. Applications and experiences of computer-based speech training. STL-QPSR (Speech Transmission Laboratory. Quarterly Progress and Status Reports). 1989. Vol. 1. pp. 59-62.

\section{REFERENCES}

1. Bessmertnaja, N. A. (2003). Organizacionnopedagogicheskie uslovija razvitija professionalnoj kompetentnosti budushhih logopedov selskih obrazovatelnyh uchrezhdenij [Organizational and pedagogical conditions for the development of professional competence of future speech therapists in rural educational institutions]. Candidate's thesis. Moscow, 168 p. [in Russian].

2. Vanieva, V. Ju. (2015). Praktiko-orientirovannyj podhod k podgotovke studentov - budushhih logopedov k professionalnoj dejatelnosti [A practiceoriented approach to train students - future speech therapists for professional activities]. Internet journal "Science Studying”. Vol. 7, No. 5. Available at: https://naukovedenie.ru/PDF/80PVN515.pdf (accessed: 04 April 2019).

3. Zhukatinskaja, E. N. (2008). Formirovanie professionalnoj kompetentnosti budushhego uchitelja- logopeda [Formation of professional competence of a future teacher - speech therapist]. Candidate's thesis. Lipetsk, 226 p. [in Russian].

4. Polat, E. S. \& Buharkina, M. Ju. (2008). Sovremennye pedagogicheskie i informacionnye tehnologii v sisteme obrazovanija [Modern pedagogical and information technologies in the education system]. Moscow, 368 p. [in Russian].

5. Stahova, L. L. (2010). Proektirovanie metodicheskoj sistemy razvitija professionalnoj kompetentnosti uchitelja-logopeda doshkolnogo obrazovatelnogo uchrezhdenija $\mathrm{v}$ uslovijah professionalnoj sredy [Constructing a methodological system of the development of professional competence of a speech therapist of a preschool educational institution in a professional environment]. Candidate's thesis. Tambov, 195 p. [in Russian].

6. Sultanova, R. M. (2005). Formirovanie professionalnoj kompetentnosti budushhego uchiteljalogopeda v uchebno-pedagogicheskoj, proizvodstvennoj praktike povyshennogo urovnja [Formation of professional competence of the teacher - future speech therapist in higher level educational and pedagogical, professional practices]. Candidate's thesis. Izhevsk, 226 p. [in Russian].

7. Chuhacheva, E. V. (2012). Formirovanie gotovnosti budushhih pedagogov k razvitiju monologicheskoj rechi detej doshkolnogo vozrasta $\mathrm{v}$ obrazovatelnom processe vuza [Formation of readiness of future teachers to develop monologue speech of preschool children in the educational process of the university]. Extended abstract of candidate's thesis. Bryansk, 23 p. [in Russian].

8. Astin, A. W. (1985). Achieving Educational Excellence. San-Francisco: Jossey-Bass Publishers, 485 p. [in English].

9. Gehris, D. O. (1982). The use of simulation in business education. Business education. No. 7. pp. 136-138.[in English].

10. Öster A-M. (1989)Applications and experiences of computer-based speech training. STL-QPSR (Speech Transmission Laboratory. Quarterly Progress and Status Reports). Vol. 1. pp. 59-62. [in English].

Стаття надійшла до редакції 27.08.2019

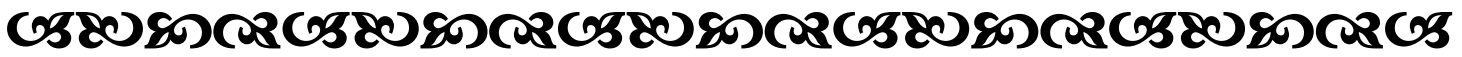

\author{
"Ятщо ви вдало виберете прачю $і$ вкладете в неї всю свою душу, то щастя само \\ знайде вас". \\ Костянтин УУшинський \\ видатний педагог-класик
}

\section{}

